\title{
Perceptions of wheat producers towards risk and risk management strategies: A case study from Turkey
}

\author{
Seyit Hayran ${ }^{1 *}$ (i)
}

${ }^{1}$ Department of Agricultural Economics, University of Cukurova, 01330, Adana, Turkey. E-mail: seyithayran@gmail.com. *Corresponding author.

ABSTRACT: In this study, risk perception of wheat producers in Turkey was examined based on a case study conducted in Bitlis Province. The data set used in the study was obtained from 157 farmers randomly. Factor analysis was employed to classify risk sources and management strategies, and then multiple regression was used to investigate the relationship between farmers perceptions and some characteristic. Results of this study have shown that economic-based risks were perceived more strongly by farmers. Farmers' also used more than one risk management strategy to minimize the impact of the risks they face. So, in order to ensure social and economic sustainability and predictability in wheat production and wheat market, the government should be considered preventive policy instruments and interventions to prevent fluctuations in input and output prices.

Key words: risk, risk management, wheat, Turkey.

Percepções de produtores de trigo para estratégias de gestão de risco:

Um estudo de caso da Turquia

RESUMO: Neste estudo a percepção de risco dos produtores de trigo na Turquia foi examinada com base em um estudo de caso realizado na provincia de Bitlis. O conjunto de dados utilizado no estudo foi obtido de 157 agricultores, aleatoriamente. A análise fatorial foi empregada para classificar as fontes de risco e as estratégias de manejo, e então a regressão múltipla foi usada para investigar a relação entre as percepções dos agricultores e algumas caracteristicas. Os resultados deste estudo mostraram que os riscos baseados na economia foram percebidos mais fortemente pelos agricultores. Os agricultores também usaram mais de uma estratégia de gerenciamento de risco para minimizar o impacto dos riscos que enfrentam. Assim, para garantir a sustentabilidade social e econômica e a previsibilidade na produção de trigo e em seu mercado, o governo deve ser considerado como um instrumento de política preventiva e intervenções para evitar flutuações nos preços de insumos e produtos.

Palavras-chave: risco, gestão de risco, trigo, Turquia.

\section{INTRODUCTION}

Agriculture is the major source of revenue and livelihood for developing countries such as Turkey, especially in rural areas, and this situation will maintain its current importance in the long run. Agriculture has an important place in these countries' GDP and contributes to capital accumulation and other sectors (service, industry etc) for development (HAYRAN \& GÜL, 2018). One of the most important barriers to the development of agricultural production to support other sectors and to meet consumption is that agriculture is under the influence of various risk factors, depending on certain situations and conditions (HAYRAN \& GÜL, 2015). The main reasons for agriculture to be a more risky business branch compared to other sectors are that agricultural production is the more sensitive to natural and climatic phenomenon such as disease, pests, extreme or under-rainfall, drought, frost, hail, flood, storm, and the agricultural sector is affected rapidly and harshly from the seasonal and cyclical fluctuations and changes in market conditions mainly due to low input and output price flexibility (HOAG, 2009). Therefore, in order to the agricultural sector to be developed to support other sectors and to provide capital accumulation, the risk behaviors of farmers should be determined and appropriate risk management strategies should be developed. It is important to understand how farmers perceive the risk they face and how they perceive the management strategies to be used against these risks in order to determine and understand farmers' risk behaviors under current 
economic and institutional conditions, especially for institutions that will intervene to ensure agricultural and rural development (HARDAKER et al., 2004; MEUWISSEN et al.., 2001). Some recent studies of risk perception and management strategies in agriculture in Turkey have focused on some agricultural production branches such as dairy farming (AKCAOZ et al., 2009a; HAYRAN \& GÜL, 2015), strawberry production (AGIR et al., 2015), olive farming (CUKUR et al., 2011), tobacco production (AKCAOZ et al., 2010). However, as a result of the literature review, a risk perception study focusing on wheat production could not be reported in Turkey. Yet, wheat farmers' perception of risk factors and management strategies has received some attention from foreign researchers in developing economies (AHMAD et al., 2019; MOHAMAD ISAM NABIL, 2014). Because of the absence of empirical studies in Turkey, the knowledge about wheat farmers' perception of risk and risk strategies is insufficient. The aim of this study was to investigate the risk perceptions of wheat producers and the determinants of perceptions in Bitlis. So, this study extended previous literature by analyzed wheat farmers' risk perceptions in a developing economy and examined the importance of risk and risk strategies as well as their relationship with some characteristics of farmers. As a result of this paper, some recommendations offered to policy-makers and institutions concerned with the development of wheat production in a developing country such as Turkey.

\section{MATERIALS AND METHODS}

This study was based on a cross-section survey of wheat farms carried out in 2018 in rural area of Bitlis province of Turkey. The main reason for choosing this region as the research area was that wheat was cultivated in $26 \%$ of the total agricultural land in Bitlis Province (134,955 ha) in 2018. And also, $31.95 \%$ of the total field crops production in Bitlis was wheat in 2018. So, the rural economy is largely based on wheat farming in the region (TÜIKK, 2019). Bitlis Province is located in Eastern Anatolia Region of the Republic of Turkey and its western neighbor is Batman, the eastern neighbors are Van and Van Lake, the northern neighbor is Mus and the southern neighbor is Siirt. The research area is shown in figure 1.

The data set used in this research was obtained from farmers in Bitlis province. A cross sectional survey method was used in this study during the period of November - December 2018 in Bitlis. One hundred and fifty seven randomly selected farmers were visited to obtain data with the help of enumerators. The instrument for data collection was a structured questionnaire that consists of two sections. The first section consisted of risk and risk management strategies designed to assess the farmers' risk perception. These were prepared taking into account the previous studies about risk perception (AKCAOZ et al., 2010; AKÇAÖZ et al., 2006a; AKÇAÖZ et al., 2006b; ASRAVOR, 2018; BOTTERILL \& MAZUR, 2004; CUKUR et al.,

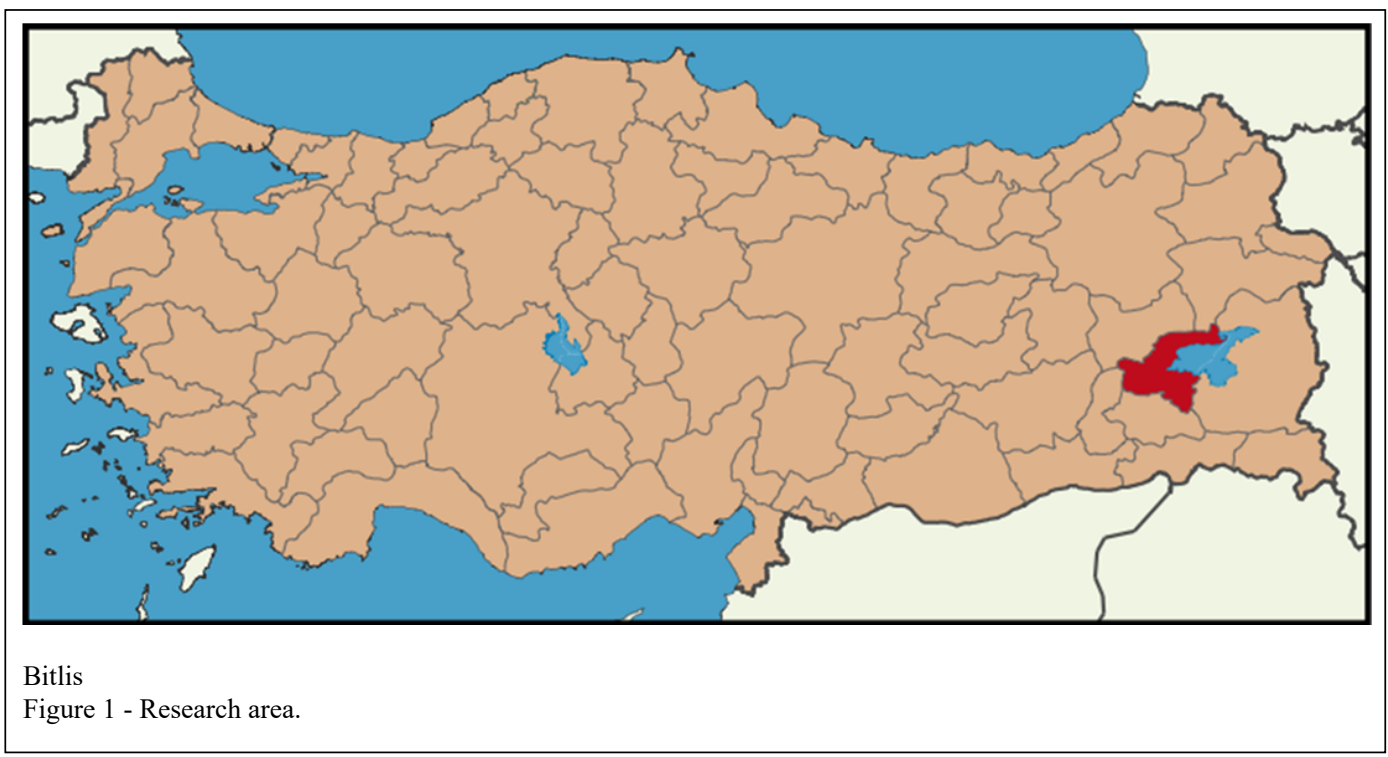

Ciência Rural, v.49, n.12, 2019. 
2011; HAYRAN et al., 2015; LIEN et al., 2006), and agricultural and socioeconomic structure of the research area (ANONYMOUS, 2006). In order to determine farmers' risk perception, they were presented and asked to rating according to their own perception of risk and risk strategies which prepared in accordance with the five-point Likert scale of Entirely Agree, Agree, Moderate Agree, Disagree and Entirely Disagree with appointing a weight of 5, 4, 3, 2 and 1 for all items.

\section{Data analysis}

In this study, descriptive statistics such as mean and standard deviation were used to determine the most important risk sources and risk management strategies according to the perceptions of wheat farmers. Factor analysis (principal component analysis) was used to gather various risk sources and risk management strategies under a smaller number of components. Factors were assessed with eigenvalues greater than 1 and varimax rotation was used. In the multiple regression model, ordinary least squares method was used for estimating the coefficients related to the relationship between socioeconomic variables and perceived risk and management strategies, and factor scores were used as independent variables (ALPAR, 2011; BISHU et al., 2018; GEBREEGZIABHER \& TADESSE, 2014; HAIR et al., 1994; HAYRAN \& GÜL, 2015). The Kaiser-Meyer-Olkin measure of sampling adequacy (KMO) and Bartlett's Test of Sphericity were used to check whether risk and risk management strategies scales appropriate for factor analysis. The KMO values of $75.80 \%$ and $73.60 \%$ for risk sources and risk management strategies scale, respectively. Bartlett's Tests of Sphericity were significant at p-values $<0.000$ for two scales. These values implied that both the risk sources scale and the risk management strategies scale were suitable for factor analysis. I interpreted variables with factor loading greater than 0.40 . I used Cronbach's alpha in order to check the internal reliability of scales (CRONBACH, 1951). The Cronbach's alpha values found as 0.839 and 0.790 for risk source and risk management strategies scales, respectively. The correlation coefficients between all of the independent variables used in the regression analysis were not significant and the variance inflation factors for all variables were less than 1.7. These values indicated that there were not multicollinearity problems (GUJARATI, 2009). It was investigated whatever there were heteroskedasticity problems for variables used in regression analysis. Results of the Breusch-Pagan test showed heteroskedasticity was not a problem for variables which were statically significant at $\mathrm{P}$-values $<0.05$. Independent variables used in the regression analysis and their descriptive statistics were shown in the table 1 .

\section{RESULTS AND DISCUSSION}

\section{Socioeconomic characteristics of farmers}

$1.28 \%$ of the farmers $(\mathrm{n}=2)$ were female and $98.72 \%(\mathrm{n}=155)$ were male; their age ranged from 23 to 75 and the mean age was 47.73 years (SD: 10.36). Farmers' education was mid-level; on average, the number of years in school of farmers was 6.35 years (SD: 3.58 ). The mean household size was 7.54 members (SD: 3.11). Farm sizes ranged from 0.3 to 281 ha and the average farm size was 2.36 ha (SD: 3.99). The average annual income of farmers was $61,290.66$ TL. Distance of the surveyed farms from the main road varied from 0.00 to $35.00 \mathrm{~km}$ and an average of $6.71 \mathrm{~km}(\mathrm{SD}: 7.38) .28 \%(\mathrm{n}=44)$ of the respondents had non-farm income sources and $72 \%$ $(\mathrm{n}=113)$ had not. $45.90 \%$ of the farmers were not only engaged in vegetal production but also in animal production.

\section{Perceptions of risk}

In total, 24 risk sources were considered in the wheat farming based on theory, empirical study, and agricultural and socioeconomic structure of the

Table 1 - The independent variables used in the regression analysis and their descriptive statistics.

\begin{tabular}{lccccc}
\hline Variable & Description & Mean & SD & Min & Max \\
\hline Age & Age of household head & 47.73 & 10.36 & 23 & 75 \\
Education & Years of schooling & 6.35 & 3.58 & 0 & 15 \\
Household size & Number of members in the household & 7.54 & 3.11 & 2 & 25 \\
Log-Income & log of household's annual income in TL & 4.55 & 0.41 & 3.65 & 6.00 \\
Farm size & Total landholding as decar & 236.50 & 399.28 & 3.00 & $2,810.00$ \\
\hline
\end{tabular}

Ciência Rural, v.49, n.12, 2019. 
research area depending on the various bibliographies mentioned in the material section. Farmers were asked to rate each risk source on a Likert scale to express how significant they perceived each source of risk in terms of economics and technical performance of wheat production. The communalities, descriptive statistics and results of factor analysis of wheat farmers' perception of each risk sources were showed in the table 2. Statistics of risk sources were presented in decreasing order of relevance to the wheat production. According to the perceptions of farmers, the most important and relevant risk source was defined as "cost and variability of fuel prices". Soil tillage, sowing, fertilization, spraying, and harvesting operations are carried out with the pulling force, and an average of $89.61 \mathrm{lt} / \mathrm{ha}$ of fuel is used to achieve this force in Turkey (OZÇELIK \& ÖZER, 2006). So, the increases or fluctuations in fuel prices negatively affect wheat farmers' economic success and/or future projections on wheat price, revenues, profits, and other decisions. In fact, CINAR \& YILMAZ (2017) reported that shocks generated at fuel prices account for about $32 \%$ to $33 \%$ of the prediction error variance on wheat prices in Turkey. "Cost and variability in input prices other than fuel such as seed, fertilizer, and pesticide etc.", "the deficient of the minimum price of wheat announced by TMO (The Turkish Grain Boards)", "high interest rates", "debt situation", and "general economic situation of the country" were identified as top-rated risk sources, respectively. Standard deviation values of the most important/ relevant risk sources that farmers rated were under 1.00. This showed that there was a consensus among farmers about economic risks.

A factor analysis on the risk scale had conducted using principal component analysis by varimax rotation. Five components, explaining $56.689 \%$ of the total variance, with Eigenvalues greater than 1.00 were delineated. Component 1 had high loading on diseases and pests, technological and market problems. Marketing problem is encountered by the farmers that could be correlated with

Table 2 - Descriptive statistics and varimax rotated factor loadings for the risk sources scale.

\begin{tabular}{|c|c|c|c|c|c|c|c|}
\hline \multirow[t]{2}{*}{ Risk Sources } & \multirow[t]{2}{*}{ Mean } & \multirow[t]{2}{*}{$\mathrm{SD}$} & \multicolumn{5}{|c|}{----------------------Component---------------------' } \\
\hline & & & 1 & 2 & 3 & 4 & 5 \\
\hline Cost and variability of fuel prices & 4.46 & 0.86 & -0.133 & 0.349 & 0.377 & -0.614 & 0.053 \\
\hline Cost and variability of input prices other than fuel & 4.36 & 0.78 & 0.083 & 0.241 & 0.153 & -0.702 & 0.197 \\
\hline The deficient of the minimum price of wheat announced by TMO. & 4.33 & 0.8 & -0.041 & 0.663 & 0.255 & -0.225 & -0.064 \\
\hline High interest rates & 4.20 & 0.95 & -0.067 & 0.749 & -0.034 & 0.164 & 0.277 \\
\hline Debt situation & 4.17 & 0.88 & 0.037 & 0.732 & 0.026 & -0.121 & 0.083 \\
\hline General economic situation of the country & 4.08 & 0.83 & 0.008 & 0.328 & 0.680 & 0.124 & 0.094 \\
\hline Lack of agricultural support payments & 3.97 & 0.88 & 0.022 & 0.082 & 0.746 & -0.112 & -0.180 \\
\hline Variability in wheat prices & 3.92 & 0.86 & 0.256 & 0.629 & 0.265 & 0.040 & -0.078 \\
\hline Uncertainty in government policies towards wheat & 3.83 & 0.99 & -0.016 & 0.170 & 0.579 & -0.027 & 0.341 \\
\hline Small farm size & 3.81 & 0.98 & 0.335 & 0.335 & 0.258 & -0.039 & -0.457 \\
\hline Foreign relations of the Turkey & 3.55 & 1.08 & 0.469 & 0.033 & 0.625 & 0.072 & 0.132 \\
\hline Changes in climate conditions & 3.52 & 0.86 & 0.351 & 0.463 & 0.309 & -0.097 & 0.091 \\
\hline Lack of infrastructure & 3.48 & 1.05 & 0.257 & 0.262 & 0.178 & 0.279 & 0.445 \\
\hline Diseases and pests & 3.32 & 0.96 & 0.510 & 0.382 & 0.064 & -0.203 & 0.360 \\
\hline Failure to follow technology & 3.32 & 0.86 & 0.664 & 0.010 & 0.088 & 0.126 & 0.094 \\
\hline Frost & 3.27 & 1.00 & 0.005 & 0.330 & 0.214 & 0.172 & 0.568 \\
\hline Shortage of storage facilities & 3.17 & 1.01 & 0.410 & -0.061 & 0.046 & -0.125 & 0.744 \\
\hline Shortage of tools and machinery & 3.08 & 0.95 & 0.737 & 0.026 & 0.063 & 0.236 & -0.220 \\
\hline Shortage of information about the market & 3.07 & 0.98 & 0.668 & -0.043 & 0.232 & -0.058 & 0.196 \\
\hline Shortage of technical knowledge & 3.03 & 0.93 & 0.661 & 0.068 & -0.186 & 0.099 & -0.021 \\
\hline Marketing problems & 3.02 & 1.13 & 0.733 & 0.125 & -0.022 & 0.143 & 0.257 \\
\hline Problems in finding foreign labor & 2.83 & 1.10 & 0.286 & 0.184 & 0.196 & 0.623 & 0.097 \\
\hline Shortage of family labor & 2.69 & 1.02 & 0.139 & -0.054 & 0.173 & 0.605 & 0.264 \\
\hline Occupational accidents and health problems & 2.35 & 0.90 & 0.160 & 0.210 & -0.346 & 0.479 & 0.443 \\
\hline Total variance explained (TVE) (\%) & & & 22.424 & 13.605 & 8.141 & 6.588 & 5.931 \\
\hline Cumulative TVE (\%) & & & 22.424 & 36.029 & 44.17 & 5.758 & 56.689 \\
\hline
\end{tabular}

Ciência Rural, v.49, n.12, 2019. 
insufficient information about the market, inability to follow the technology, lack of technical knowledge, inability to access the necessary technical equipment for wheat production, and wheat quality decrease due to diseases and pests. Component 1 was named as marketing and technology risk. Component 2 had high loading on financial risk and climate change was affected by the deficient of the minimum price of wheat announced by TMO, high interest rates, debt situation, variability in wheat prices, and changes in climate conditions. The institutional risks of wheat farmers in component 3 was affected by general economic situation of the country, lack of agricultural support payments, uncertainty in government policies towards wheat production and wheat market, and foreign relations of Turkey. The price and human risk of farmers in component 4 was affected by cost and variability in input price, problems in finding foreign labor, shortage of family labor, and occupational accidents and health problems. Infrastructure and frost risk in component 5 was affected by small farm size, lack of infrastructure, frost, shortage of storage facilities.

As a result of this study, it can be said that wheat farmers sense economic-based risk sources as the most important sources of risk that affect the performance of their farms. Economicbased risk sources such as price risk were perceived as the most important sources of risk by farmers in many studies conducted in both Turkey and foreign countries (AKCAOZ et al., 2010; BERGFJORD, 2009; FLATEN et al., 2005; GEBREEGZIABHER AND TADESSE, 2014; HAYRAN \& GÜL, 2015; HAYRAN et al., 2015). Inflation and input shortages stay an important matter in developing countries due to economic uncertainties and price fluctuations. Agricultural input and output prices do not remain stable and timely input accessibility are usually considered a vital risk to farm survival (DAMBA TAHIDU, 2017). In order to ensure social and economic sustainability and predictability in wheat production and wheat market, the government should be considered preventive policy instruments and interventions to prevent fluctuations and an increase in input prices. The main duty of the TMO (The Turkish Grain Boards) are to protect the farmer by preventing the excessive price decline by increasing the purchase amount when production is increased; To protect the consumer by decreasing the purchase amount and/or supplying cereals to the market when the production is decreasing. So, TMO should focus on price policy that can meet the cost of wheat and create a balance in the wheat market.

\section{Perceptions of risk management strategies}

For the risk management strategies, I considered 17 risk management strategies in the wheat production based on theory and empirical studies. Based on the ranking, "agricultural credit", "managing and reducing debt", "planning expenditures", "disease and pest monitoring and early intervention", and "crop animal integration" perceived as the five most effective risk management strategies of wheat farmers. In factor analysis, five components with Eigenvalues greater than 1 were identified. Component 1 represented diversification and planning by "agricultural credit", "planning expenditures", "crop - animal integration", "cultivate more than one crop". Component 1 was named as diversification and planning. With high loadings on "cooperative partnership", "contract agriculture", "futures markets and commodity exchanges", "agricultural insurance", and "keeping record", component 2 was named as Organization. Component 3 had high loadings on "gathering market information", "use of modern irrigation techniques", and "selling products at different times" (Market network and irrigation). Component 4 was named as management and optimization because that component 4 has high loading by "managing and reducing debt", "disease and pest monitoring and early intervention", and "optimization resource use". Component 5 named as off-farm income. This component had high loading by "investing off-farm" and "farm members working off-farm" (Table 3).

Production diversification was perceived as an effective strategy in the wheat farmers in order to manage risk. Any farm that has production diversification will be affected minimally by fluctuations in yield and price at different times and periods (AKÇAÖZ \& ÖZKAN, 2002). Thus, agricultural policy should be focus on support and motivate farmers to cultivate other crops and making livestock. Use of agricultural credit and managing and reducing debt remained the most effective risk management strategies. Modern agriculture requires the use of inputs such as productive seeds / fertilizers, pesticides, concentrate feed, and specialized workforce. The availability of these at appropriate time and sufficient quantities leads to a continuous cash outflow. However, due to the nature of agriculture, farmers are able to earn income once or several times in a year depending on the harvest period; although they face continuous cash outflow (BERK, 2019). It is necessary that identifying the factors affecting the credit usage of the farmers and the main constraints and expanded the accessibility of farmers to the credit. Devising well-designed and suitable

Ciência Rural, v.49, n.12, 2019. 
Table 3 - Descriptive statistics and varimax rotated factor loadings for the risk management strategies scale.

\begin{tabular}{|c|c|c|c|c|c|c|c|}
\hline \multirow[t]{2}{*}{ Risk Strategies } & \multirow[t]{2}{*}{ Mean } & \multirow[t]{2}{*}{$\mathrm{SD}$} & \multicolumn{5}{|c|}{-------------------------------'Component---------------------------- } \\
\hline & & & 1 & 2 & 3 & 4 & 5 \\
\hline Agricultural credit & 4.52 & 0.75 & 0.632 & 0.027 & -0.027 & 0.279 & 0.220 \\
\hline Managing and reducing debt & 4.39 & 0.75 & 0.199 & 0.104 & 0.193 & 0.743 & 0.341 \\
\hline Planning expenditures & 4.22 & 0.78 & 0.698 & 0.033 & 0.013 & 0.294 & 0.207 \\
\hline Disease and pest monitoring and early intervention & 4.20 & 0.73 & 0.180 & 0.097 & 0.356 & 0.655 & 0.196 \\
\hline Crop - animal integration & 4.02 & 0.86 & 0.775 & -0.107 & 0.263 & -0.077 & 0.055 \\
\hline Cultivate more than one crop & 3.93 & 0.90 & 0.735 & 0.203 & 0.211 & 0.103 & 0.055 \\
\hline Gathering market information & 3.86 & 0.84 & 0.174 & 0.117 & 0.709 & 0.291 & 0.144 \\
\hline Investing off-farm & 3.83 & 0.88 & 0.189 & -0.171 & 0.293 & 0.157 & 0.701 \\
\hline Optimization resource use & 3.78 & 0.84 & 0.090 & -0.162 & -0.010 & 0.717 & -0.265 \\
\hline Use of modern irrigation techniques & 3.78 & 0.91 & 0.308 & 0.269 & 0.460 & 0.111 & -0.338 \\
\hline Keeping record & 3.71 & 1.03 & 0.143 & 0.789 & -0.270 & 0.033 & -0.139 \\
\hline Selling products at different times & 3.67 & 0.92 & 0.064 & -0.014 & 0.807 & 0.129 & 0.103 \\
\hline Agricultural insurance & 3.65 & 1.11 & -0.090 & 0.844 & 0.139 & 0.151 & -0.095 \\
\hline Farm members working off-farm & 3.64 & 1.13 & 0.245 & 0.047 & -0.003 & -0.002 & 0.828 \\
\hline Cooperative partnership & 3.50 & 1.02 & -0.007 & 0.737 & 0.319 & -0.127 & 0.196 \\
\hline Contract agriculture & 3.39 & 1.04 & 0.350 & 0.407 & 0.260 & -0.195 & -0.279 \\
\hline Futures markets and commodity exchanges & 3.24 & 1.09 & 0.213 & 0.427 & 0.453 & -0.108 & 0.033 \\
\hline Total variance explained (TVE) (\%) & & & 14.88 & 14.38 & 12.92 & 11.20 & 10.54 \\
\hline Cumulative TVE (\%) & & & 14.88 & 29.25 & 42.17 & 53.37 & 63.91 \\
\hline
\end{tabular}

financial policies and formed essential institutions which developed wheat farmers' credit accessibility to cope with current and emerging risk in the future would be important. For this, Agricultural Credit Cooperatives in the region should be supported and microcredit institutions should be expanded. Disease and pest monitoring and early intervention remained one of the most effective risk management strategies in wheat farmers to reduce disease and pest damages. This implies the need for governmental support in providing adequate plant production services, competent plant protection specialist, and affordable pesticide to overcome plant health issues. And also, disease and pest resistant wheat varieties need to be developed. For this purpose, universities and other research institutions should focus on breeding wheat varieties which resistant disease and pest. The absence and/or ineffectiveness of well-organized agricultural cooperatives, future markets/commodity exchanges, contracted production models, and sufficient market information have adversely affected wheat farmers' economic and technical performance. Likewise, this situation has deprived the wheat products industry's accessibility to sufficient and high-quality raw material and created discouraging obstacles to invest in this industry. This implies the need for further attention towards the expansion of cooperatives, future markets/ commodity exchanges, marketing facilities, and contracted production models so as to improve the wheat farming and wheat products industry in the long run. In fact, DUGUMA (2016) stated that agricultural cooperatives are an important risk management tool that helps their members to select cash crops and to increase productivity and farm income. According to the results of a study conducted in Turkey, with the futures contracts, wheat farmers may have the opportunity to determine the price of wheat to be harvested at a certain date in the future. Thus, the farmers will be able to protect themselves against the risks to be incurred in case of prices fluctuation. Conversely, companies that use wheat as raw materials will have the opportunity to protect themselves against the price increases of these agricultural products by fixing the prices for a certain date in the future with these contracts (KAYHAN \& OKUR, 2017). TOSUN et al (2014), stated the importance of licensed warehousing system as a strategy to coping with risks such as price fluctuations faced by farmers and can reduce the risk of food safety in strategic products such as wheat in Turkey. SAQIB et al (2016), reported that forward contracting is a significant strategy used by farmers to avoid various risk such as the price risk fluctuation. Government role in expanding extension service and infrastructure such as licensed warehousing help to strengthen the risk

Ciência Rural, v.49, n.12, 2019. 
management strategies and may facilitate product sales in different periods in the year. Off-farm income was perceived as one of the effective strategies in the wheat farmers to manage risk. Thus, development policy should assist and drive self-employment and wage employment in the research area. Off-farm income as risk management strategies will continue to increase, especially depending on future risk and uncertainties about climate change and fluctuating food prices in the agricultural sector (PING ET AL, 2016).

\section{Farmers' risk perceptions related to socioeconomic characteristics}

Ordinary least squares (OLS) multiple regression analysis was used to examine the relationship between farmers' perception of risks, and their some socioeconomic characteristics. Regression coefficients and the goodness-of-fit measures of the models were reported in table 4 . Variables that are significant at p-values $<0.01,0.05$ and 0.10 were considered. The education level of the farmers was not included in the regression model because of that this variable had a negative and significant correlation with their family size and their age; and also, had a positive and significant correlation with their accessibility to off-farm income sources (Table 4).

Four of the five regression models established to examine the relationship between risk perceptions and some socio-economic characteristics of farmers were found to be statistically significant. In contrast to expectation, log-distance had a statistically significant and negative coefficient related to financial risk and climate change. This finding showed that the operators of farms closer to the main road perceived financial risks more important. Log-distance variable had a statistically significant and positive relationship with institutional risks and had a statistically significant and positive relationship with price and human risks. Contrary to expectations, farmers with small farmland perceived price and human risk to be greater compared to farmers with large farmland, but they perceived infrastructure and frost risk more important. The price and human risk included cost and variability of fuel prices, cost and variability of input prices other than fuel, problems in finding foreign labor, shortage of family labor, occupational accidents and health problems. Farmers with large farmland for operated their agricultural activities on a large scale were expected to be more sensitive to the risks in this group because they were expected to care more about input prices and labor costs, while those with less farmland remain relatively insulated from these requirements. Farmers with larger family size perceived infrastructure and frost risks to be less relevant compared to those with smaller families. Infrastructure and frost risk included small farm size, lack of infrastructure, frost, shortage of storage facilities. This is probably due to larger family size has more labor that can be engaged both off-farm work that will contribute to family livelihood and preventions to be taken urgently to prevent the risk of frost.

\section{Farmers' risk management strategies related to socioeconomic characteristics}

OLS multiple regression analysis was used to examine the relationship between farmers' perception of risk management strategies, and some socioeconomic characteristics and risk perceptions. The regression coefficients and the goodness-of-fit measures of the models were reported in Table 5 . All models were significant at $p$-values $<0.001$. The

Table 4 - Multiple regression analysis results for the risk sources.

\begin{tabular}{|c|c|c|c|c|c|}
\hline \multirow[t]{2}{*}{ Independent Variables } & 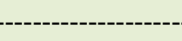 & --------------------.' & Risk Sources-------- & ----------- & 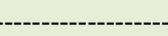 \\
\hline & $\begin{array}{l}\text { Marketing and } \\
\text { Technology }\end{array}$ & $\begin{array}{c}\text { Financial Risk and } \\
\text { Climate Change }\end{array}$ & Institutional Risks & $\begin{array}{c}\text { Price and } \\
\text { Human Risk }\end{array}$ & $\begin{array}{c}\text { Infrastructure } \\
\text { and Frost }\end{array}$ \\
\hline Constant & -0.587 & 0.611 & 0.171 & -0.312 & -0.110 \\
\hline Age & 0.056 & -0.063 & 0.051 & 0.037 & 0.096 \\
\hline Family Size & 0.077 & 0.046 & -0.023 & -0.090 & $-0.192^{* *}$ \\
\hline Farm Size & -0.163 & 0.047 & 0.042 & $-0.190^{* *}$ & $0.230^{* *}$ \\
\hline $\begin{array}{l}\text { Accessibility to Off- } \\
\text { Farm Income }\end{array}$ & 0.016 & -0.105 & 0.076 & 0.065 & -0.057 \\
\hline Log-Distance & 0.162 & $-0.262^{* *}$ & $-0.280^{* *}$ & $0.297^{*}$ & 0.007 \\
\hline Adjusted R Square & 0.260 & $0.057^{* *}$ & $0.051^{* *}$ & $0.089^{* *}$ & $0.059^{* *}$ \\
\hline
\end{tabular}

Note: Variables and models significant at ${ }^{*} \mathrm{P}<0.10,{ }^{* *} \mathrm{P}<0.05,{ }^{* * *} \mathrm{P}<0.01$. 
Table 5 - Multiple regression analysis results for the risk management strategies.

\begin{tabular}{|c|c|c|c|c|c|}
\hline \multirow[t]{2}{*}{ Independent Variables } & \multicolumn{5}{|c|}{ 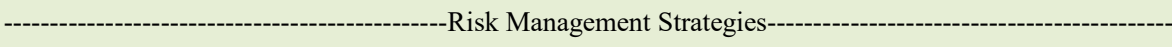 } \\
\hline & $\begin{array}{l}\text { Diversification and } \\
\text { Planning }\end{array}$ & Organization & $\begin{array}{c}\text { Market Network } \\
\text { and Irrigation }\end{array}$ & $\begin{array}{l}\text { Management and } \\
\text { Optimization }\end{array}$ & $\begin{array}{l}\text { Off-Farm } \\
\text { Income }\end{array}$ \\
\hline Constant & $-0.903^{* *}$ & -0.079 & -0.127 & 0.046 & -0.176 \\
\hline Age & $0.216^{*}$ & 0.014 & -0.082 & 0.012 & 0.023 \\
\hline Family Size & 0.003 & -0.055 & 0.086 & -0.100 & 0.113 \\
\hline Farm Size & -0.099 & -0.015 & -0.047 & -0.024 & -0.037 \\
\hline $\begin{array}{l}\text { Accessibility to Off-Farm } \\
\text { Income }\end{array}$ & 0.011 & -0.077 & $0.126^{* * *}$ & -0.050 & -0.073 \\
\hline Log-Distance & -0.026 & 0.136 & $0.163^{* *}$ & 0.125 & -0.089 \\
\hline Marketing and Technology & -0.026 & 0.096 & $0.305^{*}$ & $-0.250^{*}$ & $-0.245^{*}$ \\
\hline $\begin{array}{l}\text { Financial Risk and Climate } \\
\text { Change }\end{array}$ & $0.150^{* * *}$ & -0.101 & $0.273^{*}$ & $0.253^{*}$ & $0.253^{*}$ \\
\hline Institutional Risks & 0.059 & $0.234^{* *}$ & $0.354^{*}$ & $0.278^{*}$ & 0.098 \\
\hline Price and Human Risk & $-0.268^{*}$ & $0.312^{*}$ & 0.036 & -0.141 & $-0.166^{* *}$ \\
\hline Infrastructure and Frost & 0.093 & $0.187^{* *}$ & -0.048 & $0.168^{* *}$ & $-0.359^{*}$ \\
\hline Adjusted R Square & $0.092^{*}$ & $0.199^{*}$ & $0.318^{*}$ & $0.177^{*}$ & $0.327^{*}$ \\
\hline
\end{tabular}

Note: Variables and models significant at ${ }^{*} \mathrm{P}<0.10,{ }^{* *} \mathrm{P}<0.05,{ }^{* * *} \mathrm{P}<0.01$

education level of the farmers was not included in the regression model because of that this variable had a negative and significant correlation with their family size and their age; had a positive and significant correlation with their accessibility to off-farm income sources. According to the results of the regression analysis, there was a statistically significant and positive relationship between farmers' perceptions towards diversification and planning strategy and their ages. Elderly farmers, depending on the negative experiences in the past years, are more likely to utilize diversification and planning strategy in order to reduce and minimize the effects of possible risks in the future. The market network and irrigation strategy was perceived more important by farmers who have access to off-farms income and also, these farms are far from the main road (Table 5).

Wheat farmers who perceived financial risk and climate change as important were associated with multiple coping responses; Diversification and Planning, Market Network and Irrigation, Management and Optimization, Off-Farm Income. Similarly, the other four risk components (Institutional Risks, Price and Human Risk, Infrastructure and Frost, Marketing and Technology) were related to more than one risk management strategy. This implies that farmers are engaged in multiple management activities and coping strategies when faced with the risk.

\section{ACKNOWLEDGMENTS}

I would like to thank Şener KALYA who is Bitlis Provincial Director of the Ministry of Agriculture and Forestry for his support in the data collection stage of research.

\section{DECLARATION OF CONFLICT OF INTERESTS}

The authors declare no conflict of interest. The founding sponsors had no role in the design of the study; in the collection, analyses, or interpretation of data; in the writing of the manuscript, and in the decision to publish the results.

\section{AUTHORS' CONTRIBUTIONS}

Data set were collected by enumerators. Other stages of the study were conducted by the author.

\section{REFERENCES}

AGIR, H. B., et al. Risk sources encountered by farmers in the open field production of strawberry and risk management strategies: a case of Menemen - Emiralen District of Izmir, Journal of Agricultural Sciences, v.21, n.1, p.13 - 25, 2015. Available from: $<$ https://doi.org/10.15832/tbd.29197>. Accessed: Jan. 1, 2019. doi: $10.15832 /$ tbd. 29197.

AHMAD, D., et al. Analysis of wheat farmers' risk perceptions and attitudes: evidence from Punjab, Pakistan, Natural Hazards, v.95, n.3, p.845 - 861, 2019. Available from: <https://doi.org/10.1007/ s11069-018-3523-5>. Accessed: Apr. 1, 2019. doi: 10.1007/ s11069-018-3523-5.

Ciência Rural, v.49, n.12, 2019. 
AKCAOZ, H., et al. Risk management strategies in dairy farming: A case study in Turkey, Journal of Animal and Veterinary Advances, v.8, n.5, p.949-958, 2009a. Available from: <https:// doi.org/10.3923/javaa.2009.949.958>. Accessed: Jan. 15, 2017. doi: 10.3923 javaa.2009.949.9585.

AKCAOZ, H., et al. Risk and sustainability in tobacco production in Turkey, Journal of Food, Agriculture \& Environment,v.8, n.3-4, p.717 - 722, 2010a. Available from: <http://apps.webofknowledge. com/full_record.do?product $=$ WOS\&search_mode $=$ GeneralSea rch\&qid $=4 \&$ SID $=$ C3PLvhBLaiOZLAJviqi\&page $=1 \&$ doc $=1>$. Accessed: Mar. 15, 2017.

AKCAOZ, H., et al. Risk management and sustainability in banana production: A case study from Turkey, Journal of Food, Agriculture \& Environment, v.7, n.2, p.283-294, 2010b. Available from: <http://apps.webofknowledge.com/ full record.do? product $=$ WOS\& search mode $=$ GeneralSearch $\&$ qid $=4 \&$ SID $=$ E3XwaWih8nkwo9fT8Ua\&page $=1 \&$ doc $=1>$. Accessed: Mar. 15, 2017.

AKCAOZ, H., et al. Tarımsal Üretimde Risk Kaynakları ve Risk Stratejileri: Antalya İli Örneği, Akdeniz Üniversitesi Ziraat Fakültesi Dergisi, v.19, n.1, p.89-97, 2006a. Available from: $<$ https://dergipark.org.tr/tr/pub/akdenizfderg/issue/1578/19576>. Accessed: Mar. 1, 2019.

AKÇAÖZ, H., et al. Antalya İlinde Tarımsal Üretimde Risk Yönetimi Ve Tarım Sigortası Uygulamaları, Tekirdağ Ziraat Fakültesi Dergisi, v.3, n.2, p.93-103, 2006b. Available from: $<$ https://dergipark.org.tr/tr/download/article-file/178562>. Accessed: Mar. 15, 2018.

AKÇAÖZ, H., \& ÖZKAN, B. Tarımsal Üretimde Karşılaşılan Riskler ve Uygulanabilecek Stratejiler. In "Türkiye V. Tarım Ekonomisi Kongresi”, v.1, pp. 77 - 82, Erzurum, Turkey, 2002. Available from: <http://www.tarimarsiv.com/wp-content/ uploads/2017/04/77-82.pdf>. Accessed: Jan. 18, 2019.

ALPAR, R. (2011). Uygulamalı Çok Değiş̧enli İstatistiksel Yöntemler (3. Baskı), Ankara: Detay Yayıncılık, Turkey, 2011.

ANONYMOUS. Bitlis İli 2005 Yılı Tarım Master Planı, Bitlis Valiliği Tarım ve Orman Bakanlığı İl Müdürlügüu, Bitlis, Turkey, 2006.

ASRAVOR, R. K. Farmers' risk preference and the adoption of risk management strategies in Northern Ghana, Journal of Environmental Planning and Management, v.62, n.5, p.881-900, 2019. Available from: <https://doi.org/10.1080 /09640568.2018.1452724>. Accessed: Mar. 18, 2018. doi: $10.1080 / 09640568.2018 .1452724$.

BERK, A. Niğde ve Karaman İllerinde çiftçilerin tarımsal kredi kullanım kararlarını etkileyen faktörlerin belirlenmesi, Turkish Journal of Agriculture - Food Science and Technology, v.7, n.8, p.1182-1188, 2019. Available from: <https://doi.org/10.24925 turjaf.v7i8.1182-1188.2619>. Accessed: Aug. 18, 2019. doi: 10.24925/turjaf.v7i8.1182-1188.2619

BISHU, K. G., et al. Cattle farmers' perceptions of risk and risk management strategies: evidence from Northern Ethiopia, Journal of Risk Research, 2018. v.21, n.5, p.579-598, 2018. Available from: <https://doi.org/10.1080 /13669877.2016.1223163>. Accessed: Aug. 18, 2019. doi: $10.1080 / 13669877.2016 .1223163$
BOTTERILL, L., \& MAZUR, N. Risk \& risk perception: a literature review, A report for the Rural Industries Research and Development Corporation, RIRDC Publication, ISBN 0642 58753 1, 2004. Available from: <https://www.agrifutures.com.au/ product/risk-and-risk-perception-a-literature-review/>. Accessed: Feb. 18, 2019.

CRONBACH, L. F. Coefficient alpha and the internal structure of tests. Psychometrika, v.16, n.3, p.297-334, 1951. Available from: $<$ https://doi.org/10.1007/BF02310555>. Accessed: Feb. 18, 2017. doi: 10.1007/BF02310555.

CUKUR, F., et al. Risks and risk strategies on olive farming in Milas district of Mugla province, Turkey. Journal of Food, Agriculture \& Environment, v.9, n.1, p.190-194, 2011. Available from: $<$ http://apps.webofknowledge.com/full_record. do? product $=$ WOS\&search_mode $=$ GeneralSearch \&qid $=7 \&$ SID $=$ E3XwaWih8nkwo9fT8Ua\&page $=1 \&$ doc $=1>$. Accessed: Feb. 18,2016

CINAR, G., \& YILMAZ, H. I. Türkiye'deki mazot fiyat şoklarının hububat sektörüne etkisi, Aydın İktisat Fakültesi Dergisi, v.2, n.2, p.101-115, 2017. Available from: <https://dergipark.org.tr/tr/ pub/aifd/issue/33315/370598>. Accessed: Jul. 16, 2018.

DAMBA TAHIDU, O. A comparative analysis on volatility transmission of inflation, exchange rates, crude oil prices with selected agricultural product prices: a case of Ghana and Turkey. 2017. Dissertation/Thesis (/PhD in Agricultural economics), Atatürk University.

DUGUMA, A. The Role of agricultural cooperatives in risk management and impact on farm income: evidence from Southern Ethiopia, Journal of Economics and Sustainable Development, v.7, n.21, p.89-99, 2016. Available from: $<$ https:// doi.org/10.11648/j.ijebo.20160404.11>. Accessed: Jul. 21, 2017. doi: $10.11648 /$ j.ijebo.20160404.11.

GEBREEGZIABHER, K., \& TADESSE, T. Risk perception and management in smallholder dairy farming in Tigray, Northern Ethiopia, Journal of Risk Research, v.17, n,3, p.367-381, 2014. Available from: <https://doi.org/10.10 80/13669877.2013.815648>. Accessed: Jul. 3, 2015. doi: $10.1080 / 13669877.2013 .815648$

GUJARATI, D. N. Basic econometrics, Tata McGraw-Hill Education, 2009.

HAIR, F. J., et al. Multivariate data analysis, McMillan Publishing Company. 3rd Edition, New York, 1994.

HARDAKER, J., et al. Coping with risk in agriculture, CABI: 1. Edition, 2004.

HAYRAN, S., \& GUL, A. Risk perception and management strategies in dairy farming: a case of Adana Province of Turkey, Turkish Journal of Agriculture - Food Science and Technology, v.3, n.12, p.952-961, 2015. Available from: <https://doi. org/10.24925/turjaf.v3i12.952-961.583>. Accessed: Jul. 3, 2017. doi: 10.24925/turjaf.v3i12.952-961.583.

HAYRAN, S., \& GUL, A. Mersin İlinde Çiftçilerin Tarımsal Kredi Kullanım Kararlarını Etkileyen Faktörler, Iğdır Üniversitesi Fen Bilimleri Enstitüsü Dergisi, v.8, n.1, p.271-277, 2018. Available from: <https://doi.org/10.21597/jist.407885>. Accessed: Mar. 3, 2019. doi: $10.21597 /$ jist. 407885 . 
HAYRAN, S., et al. Risk perception and management strategies in agricultural production: a case of Adana Province of Turkey. In "2nd International Conference on Sustainable Agriculture and Environment (2nd ICSAE)", v.1, pp.237-244, Konya, Turkey, 2015. Available from: <https://www.cabdirect.org/cabdirect/ abstract/20163289284>. Accessed: Jan. 3, 2016.

HOAG, D. Applied risk management in agriculture, United States: CRC Press; 1 edition, 2009.

KAYHAN, F., \& OKUR, A. Türkiye'de vadeli işlem ve opsiyon piyasasi ile bu piyasada yer alan emtiaya dayali sözleşmelerin değerlendirilmesi, Bankacılık ve Finansal Araștırmalar Dergisi v.7, n.4 p.1-14 ,2017. Available from: < https://dergipark.org.tr/tr/ download/article-file/320840>. Accessed: Jan. 3, 2018.

LIEN, G., et al. Management and risk characteristics of parttime and full-time farmers in Norway. Review of Agricultural Economics, v.28, n.1, p.111-131, 2006. Available from: <www. jstor.org/stable/3700850>. Accessed: Sep. 3, 2017.

MEUWISSEN, M., et al. Sharing risks in agriculture: principles and empirical results, Netherlands Journal of Agriculture Science, v.49, n.4, p.343-356, 2001. Available from: <https://doi org/10.1016/S1573-5214(01)80022-1>. Accessed: Sep. 7, 2017. doi: $0.1016 / \mathrm{S} 1573-5214(01) 80022-1$.

MOHAMAD ISAM NABIL, A. Risk attitude, risk perceptions and risk management strategies: an empirical analysis of Syrian wheat-cotton and pistachio farmers. Dissertation/Thesis (/PhD in Agricultural Sciences), Georg-August-University, 2014.
OZÇELIK, A., \& OZER, O. O. Çiftçilere yapılan kimyevi gübre desteği ve tarımsal faaliyette kullanılan mazot için destekleme ödemelerinin değerlendirilmesi, Tarım Bilimleri Dergisi, v.13, n.1, p.1-8, 2006. Available from: <https:// dergipark.org.tr/tr/pub/turkjans/issue/30559/330688>. Accessed: Jan. 7, 2019.

PING, Q., et al. Adoption of off-farm diversification income sources in managing agricultural risks among cotton farmers in Punjab Pakistan, Journal of Applied Environmental and Biological Sciences, v.6, n.8, p.47-53, 2016. Available from: $<$ https://pure.mpg.de/rest/items/item_2478815_9/component/ file_2539031/content>. Accessed: Jan. 18, 2019.

SAQİB S. E., et al. Forward contract as means for managing agriculture risk: the case of Pakistan, In "Linkages and Cooperation in Agricultural Production and Marketing in the Context of International Economic Integration", v.1, pp.127, Vietnam, 2016. Available from: <https://www.researchgate. net/publication/309703906_Forward_contract_as_means_for managing_agriculture_risk_the_case_of_Pakistan $>$. Accessed: Jul. 18, 2019.

TOSUN, D., et al. The evaluation of the warehouse receipt system for agro-food products in Turkey, Anadolu Tarım Bilimleri Dergisi, v.29, n.3, p.240-247, 2014. Available from: <https://doi. org/10.7161/anajas.2014.29.3.240-247>. Accessed: Jul. 18, 2019. doi: 10.7161/anajas.2014.29.3.240-247.

TÜİK. Available from: <http://www.tuik.gov.tr/VeriBilgi.do?alt $\mathrm{id}=1062>$. Accessed: Jan. 16, 2019. 


\section{Erratum}

In the article "Perceptions of wheat producers towards risk and risk management strategies: A case study from Turkey" published in Ciência Rural, volume 49, number 12, DOI http://dx.doi.org/10.1590/0103-8478cr20190396.

\section{In the Table 1, where we read:}

Table 1 - The independent variables used in the regression analysis and their descriptive statistics.

\begin{tabular}{lccccc}
\hline Variable & Description & Mean & SD & Min & Max \\
\hline Age & Age of household head & 47.73 & 10.36 & 23 & 75 \\
$\begin{array}{l}\text { Education } \\
\begin{array}{l}\text { Household } \\
\text { size }\end{array}\end{array}$ & $\begin{array}{c}\text { Yumber of schooling } \\
\text { household }\end{array}$ & 6.35 & 3.58 & 0 & 15 \\
$\begin{array}{l}\text { Log- } \\
\text { Income }\end{array}$ & $\begin{array}{c}\text { log of household's annual } \\
\text { income in TL }\end{array}$ & 4.54 & 3.11 & 2 & 25 \\
Farm size & Total landholding as decar & 236.50 & 399.28 & 3.00 & $2,810.00$ \\
\hline
\end{tabular}

\section{Read:}

Table 1 - The independent variables used in the regression analysis and their descriptive statistics.

\begin{tabular}{lccccc}
\hline Variable & \multicolumn{1}{c}{ Description } & Mean & SD & Min & Max \\
\hline Age & $\begin{array}{c}\text { Age of household head } \\
\text { Number of members in } \\
\text { Family Size }\end{array}$ & 47.73 & 10.36 & 23 & 75 \\
\hline Farm Size & $\begin{array}{c}\text { Total landholding as } \\
\text { decar }\end{array}$ & 236.50 & 399.28 & 3.00 & $2,810.00$ \\
$\begin{array}{l}\text { Accessibility } \\
\text { to Off-Farm }\end{array}$ & $\begin{array}{c}1 \text { for off-farm income } \\
\text { and 0 otherwise }\end{array}$ & 0,28 & 0,45 & 0 & 1 \\
$\begin{array}{l}\text { Income } \\
\begin{array}{l}\text { Log- } \\
\text { Distance }\end{array}\end{array}$ & $\begin{array}{c}\text { log of distance of farm } \\
\text { from main road in km }\end{array}$ & 0,63 & 0,41 & 0.00 & 1,54 \\
\hline
\end{tabular}

